TECHNICAL NOTES AND MANUALS

Revenue Administration:

Implementing a High-Wealth

Individual Compliance Program

John Buchanan and Lucilla McLaughlin

Fiscal Affairs Department

I NTERNATIONAL MONETARY FUND 
TECHNICAL NOTES AND MANUALS

\section{Revenue Administration: Implementing a High-Wealth Individual Compliance Program}

John Buchanan and Lucilla McLaughlin

Fiscal Affairs Department

I NTERNATIONAL MONETARY FUND 


\section{INTERNATIONAL MONETARY FUND}

Fiscal Affairs Department

Revenue Administration: Implementing a High-Wealth Individual Compliance Program

Prepared by John Buchanan and Lucilla McLaughlin

Authorized for distribution by Vitor Gaspar

April 2017

DISCLAIMER: This Technical Guidance Note should not be reported as representing the views of the IMF. The views expressed in this Note are those of the Authors and do not necessarily represent those of the IMF or IMF policy.

\begin{tabular}{|l|l|}
\hline JEL Classification Numbers: & H2O, H21, H24, H26, H31 \\
\hline Keywords: & $\begin{array}{l}\text { Tax Administration; Tax Compliance; Tax Avoidance; Tax Audit; } \\
\text { Personal Income Tax; Compliance Risk Management; High Wealth } \\
\text { Individual; Ultra-High Wealth Individual; HWI Compliance Program }\end{array}$ \\
\hline Authors' E-Mail Addresses: & $\begin{array}{l}\text { john_buchanan@att.net } \\
\text { Imclaughlin@imf.org }\end{array}$ \\
\hline
\end{tabular}




\section{TECHNICAL NOTES AND MANUALS}

\section{Revenue Administration: Implementing a High-Wealth Individual Compliance Program ${ }^{1}$}

\section{This technical note addresses the following questions:}

- What are the characteristics of a high-wealth individual (HWI)?

- Why do leading tax administrations give special attention to the HWI sector?

- What should a tax administration do when considering setting up a High-Wealth Individual Compliance Program (HWICP)?

- How should a HWICP be started and staffed?

- $\quad$ Can the Compliance Risk Management² (CRM) model be used as a basis for a HWICP?

\footnotetext{
${ }^{1}$ Lucilla McLaughlin is a Senior Economist in the Fiscal Affairs Department of the IMF. John Buchanan is a member of the IMF's roster of fiscal experts.

${ }^{2}$ Managing and Improving Compliance: Recent Developments in Compliance Risk Treatments, OECD March 2009, Revenue Administration: Developing a Taxpayer Compliance Program, IMF Technical Note, November 2010.
} 


\section{CONTENTS}

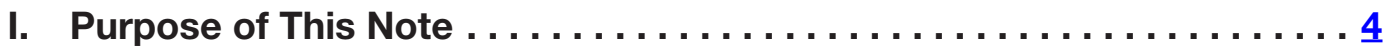

II. What Are the Characteristics of the High-Wealth Individual? . . . . . . 5

III. Why do Leading Tax Administrations Give Special Attention to the High-Wealth Individual Sector? . . . . . . . . . . . . . . . . 8

IV. What Should a Tax Administration do When Considering Setting up a High-Wealth Individual Compliance Program? . . . . . . . 10

A. Alignment of Compliance Goals With the Political and Economic Environment . . . . 11

B. Legal Authority to Support a HWICP . . . . . . . . . . . . . . . . . . 12

C. Evaluation of the Capacity to Engage with HWIs and their Intermediaries . . . . . . 15

D. Data and Information . . . . . . . . . . . . . . . . . . . . . . . . . . 17

V. How Should a High-Wealth Individual Compliance Program be Started, Communicated, and Staffed? . . . . . . . . . . . . . . . 17

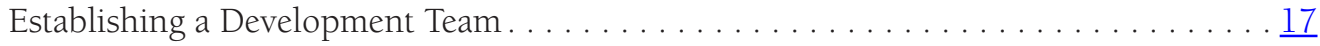

Defining the HWI Population . . . . . . . . . . . . . . . . . . 17

Publishing the Strategy . . . . . . . . . . . . . . . . . . . . . . . 18

Implementation Phase . . . . . . . . . . . . . . . . . . . . . 18

Staffing the Operational Unit. . . . . . . . . . . . . . . . . . . . 18

VI. Can the Compliance Risk Management Model be Used as a Basis for a High-Wealth Individual Compliance Program? . . . . . . 19

Phase 1: Define-Identify the Population . . . . . . . . . . . . . . . . . 20

Phase 2: Identify HWI Compliance Risks (Risk Mapping) . . . . . . . . . . . . . 20

Phase 3: Assess and Prioritize Compliance Risks . . . . . . . . . . . . . . 20

Phase 4: Analyze Compliance Behavior . . . . . . . . . . . . . . . . . . . . 21

Phase 5: Determine Treatment Strategies . . . . . . . . . . . . . . . . . . . . 22

Phase 6: Implement Action Plans . . . . . . . . . . . . . . . . . . . 23

Phase 7: Establish Monitoring and Reporting Mechanisms and Performance Targets. . . 23

Phase 8: Qualitative Analysis of Outcomes . . . . . . . . . . . . . . . . . . . . . 23

Vl. Summary of Key Points . . . . . . . . . . . . . . . . . . . 24

\section{Appendices}

1. Key Recommendations of the Organization for Economic Cooperation and Development $\underline{25}$

2. Questions Regarding the Taxation of Personal Income ............... 26

3. Compliance Treatment Tools Check Sheet. . . . . . . . . . . . . . . . . . . . 27

Figures

1. Shares of Personal Income Tax Liability. . . . . . . . . . . . . . . . . . . . . . $\underline{6}$

2. The Compliance Risk Management Process . . . . . . . . . . . . . . . . . . 19 


\section{ACRONYMS}

\begin{tabular}{|c|c|}
\hline AOEI & Automatic exchange of information \\
\hline ATO & Australian Taxation Office \\
\hline ATP & Aggressive tax planning \\
\hline AUD & Australian Dollar \\
\hline CRM & Compliance risk management \\
\hline CIT & Corporate income tax \\
\hline EU & European Union \\
\hline EUR & Euro \\
\hline FATCA & Foreign Account Tax Compliance Act \\
\hline GAAR & General anti-avoidance rule \\
\hline GBP & Great Britain Pound \\
\hline HMRC & Her Majesty's Revenue and Customs \\
\hline HNWI & High-net-worth individual \\
\hline HWI & High-wealth individual \\
\hline HWICP & High-wealth individual compliance program \\
\hline HWICS & High-wealth individual compliance strategy \\
\hline IDR & Indonesian Rupiah \\
\hline IMF & International Monetary Fund \\
\hline IRS & Internal Revenue Service \\
\hline IT & Information technology \\
\hline LTO & Large taxpayer office \\
\hline OECD & Organization for Economic Cooperation and Development \\
\hline PIT & Personal income tax \\
\hline UHWI & Ultra-high wealth individual \\
\hline UHNWI & Ultra-high-net-worth individual \\
\hline UK & United Kingdom \\
\hline US & United States \\
\hline USD & United States Dollar \\
\hline VCL & Voluntary compliance level \\
\hline VDI & Voluntary disclosure initiative \\
\hline
\end{tabular}




\section{PURPOSE OF THIS NOTE}

This technical note aims to guide tax administrations considering a program to enhance the tax compliance of HWIs. The note explains the rationale for a specialized compliance program for this segment of the taxpayer base and provides guidance on defining the HWI population, preparing for a program and implementing it.

The first step in meeting the many challenges presented by the HWI sector is for a tax administration to recognize the risks posed by this taxpayer segment. The HWI sector presents tax administrations with substantial and increasing compliance risks, stemming from the complexity of their financial affairs, compounded by their significance in terms of potential revenue, and their tendency to use aggressive tax planning to minimize effective tax rates. ${ }^{3}$ Failure to address compliance risks in this small but often highly visible group of taxpayers can lead to erosion of trust in the fairness of the tax administration, which will tend to reduce compliance in the wider taxpayer population.

As a next step, an administration should assess its own readiness to undertake a HWI compliance program (HWICP) and remedy any deficiencies. The note discusses factors to consider when determining readiness: these factors include assessing alignment with the reality of the political environment, the extent of authority to monitor and tax HWIs, the capacity of the tax administration to engage HWIs and their advisors, and whether there is sufficient information to support a HWICP.

The note then gives practical advice on implementing a HWICP, using the CRM ${ }^{4}$ model as the foundation for the program. The CRM approach seeks to identify the most serious compliance risks and to mitigate the risks using a range of treatments, which are designed to increase compliance and minimize the compliance gap in the most cost-effective way. Even where an administration is not ready for a full HWICP, some of the steps in this note can be followed in order to monitor HWI compliance, and at least ensure that each HWI complies with filing and payment obligations. In time, the monitoring can expand to building a profile of the wealthiest individuals, so that the administration can begin to recognize the extent of compliance risks and address them in a systematic way.

\footnotetext{
${ }^{3}$ See IMF Staff Paper Current Challenges in Revenue Mobilization: Improving Tax Compliance, April 2015.

${ }^{4}$ A framework endorsed by OECD (2009), EU (2010) and IMF (2010) for managing taxpayers' compliance by identifying risks in taxpayer segments and using the most appropriate responses to mitigate the risks.
} 


\section{WHAT ARE THE CHARACTERISTICS OF THE HIGH-WEALTH INDIVIDUAL?}

There is no standard definition of HWI, but it is generally understood to mean individuals who have accumulated net worth to the level that places them at the very top of the wealth scale in a country, or indeed globally. Net worth or wealth is defined as the value of financial assets plus real assets (land and buildings), owned by individuals and their immediate families, less their debts. The definition of wealth includes personal wealth and wealth held in trusts, and in legal entities effectively controlled by the individuals and their families.

While HWIs are sometimes defined in terms of income, they are usually more defined in terms of net wealth over a certain threshold. This technical note defines HWIs based on wealth rather than income, because income is more susceptible to fluctuation and manipulation than wealth. The definition of a HWI (sometimes called a high-net-worth individual (HNWI)) commonly used in the financial services sector is an individual or family group with a total wealth of USD 1 million or more. A further category, termed ultra-high-net-worth individual (UHNWI), usually describes those with accumulated wealth of more than USD 30 million. ${ }^{5}$ Such categories provide a useful starting point for tax administrations that wish to devise compliance programs for their high-wealth populations.

Wealth reports published annually by the banking and investment industries track the growth, financial activities, investments, and economic impact of HWIs. Some observations from published sources are:

- In 2015, an estimated 34 million HWIs worldwide had accumulated wealth of at least USD 1 million each. These individuals comprise just 0.7 percent of the world's population but control 45 percent of the world's wealth. ${ }^{6}$

- Some 211,000 HWIs globally have total wealth of USD 30 million or more. Their combined wealth is estimated to be USD 29.7 trillion. $^{7}$

- Ultra-high wealth individuals (UHWIs) are defined by Credit Suisse as those who control total wealth of over USD 50 million. They estimate that there were over 120,000 of them globally in $2015 .{ }^{8}$

- Globally, HWIs maintain more than one-quarter of their wealth portfolio in cash, the balance comprising equities ( 27 percent), real estate (18 percent), fixed income investments

\footnotetext{
${ }^{5}$ Capgemini, for example defines HNWIs as those having investable assets of USD 1 million or more, excluding primary residence, collectables, consumables and consumer durables. Those with USD 30 million or more are defined as ultra-HNWIs. 2015 World Wealth Report, Capgemini \& Royal Bank of Canada Wealth Management.

62015 Global Wealth Report, Credit Suisse.

${ }^{7} 2014$ World Ultra Wealth Report, Wealth-X and UBS

82015 Global Wealth Report, Credit Suisse.
} 
(17 percent), and alternative investments (hedge funds, derivatives, currency, commodities, and private equity) (13 percent). ${ }^{9}$

- Wealth and income inequality continue to increase. Over the last three decades the income shares of the richest one-percent of the population have increased substantially in English-speaking advanced economies, as well as in China and India. In the same period in the United States (US), the richest 0.1 percent of the population saw their share of income grow from 2.6 percent of total US income to 10.4 percent. ${ }^{10}$

Figure 1. Shares of Personal Income Tax Liability
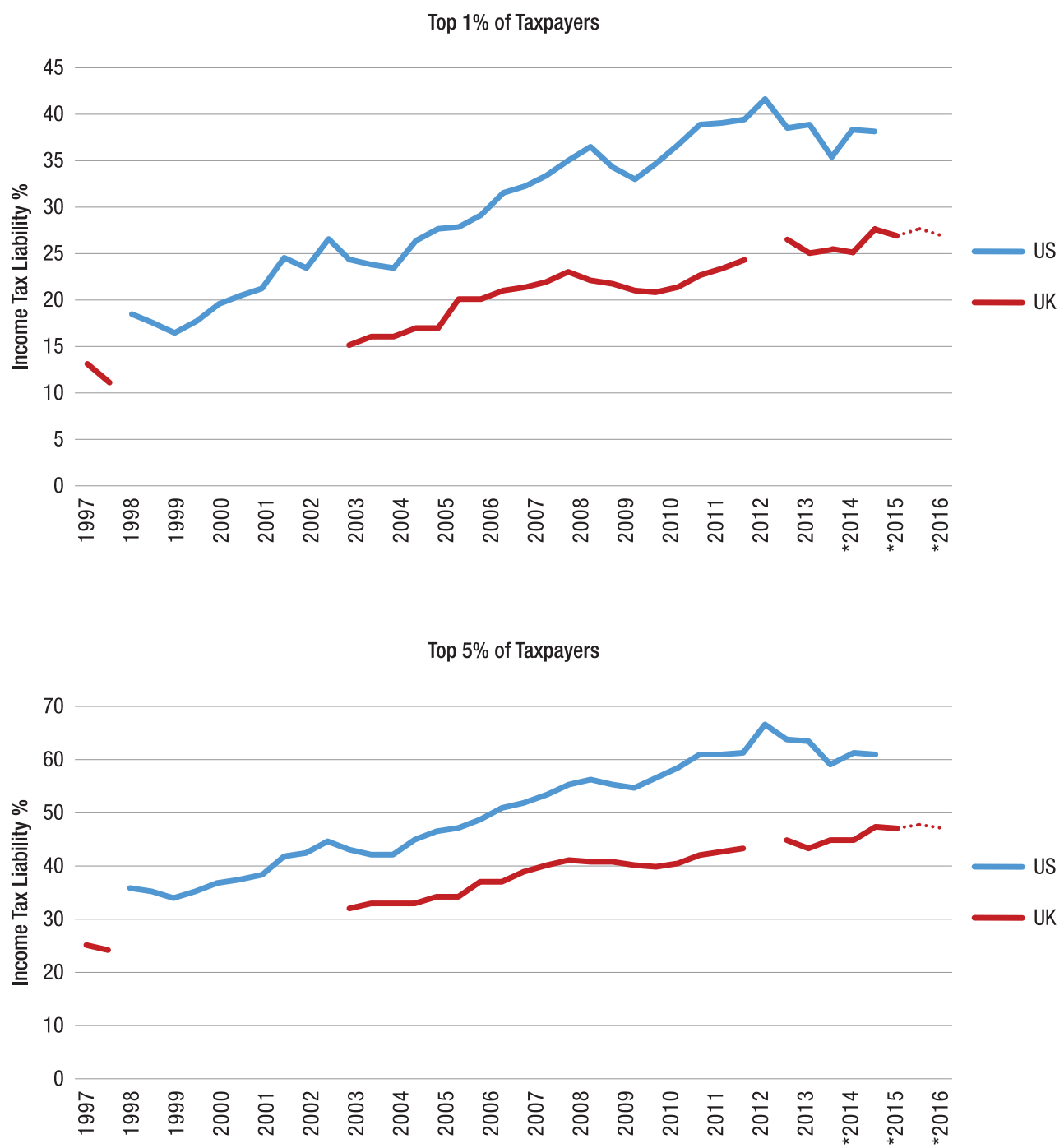

Sources: Survey of Personal Incomes (UK), Congressional Budget Office (2011) BO (US)

*Projected estimates based upon the 2013-14 Survey of Personal Incomes using economic assumptions consistent with the OBR's March 2016 economic and fiscal outlook.

${ }^{9} 2015$ World Wealth Report, Capgemini \& Royal Bank of Canada Wealth Management.

${ }^{10}$ Fiscal Policy and Income Inequality, IMF Policy Paper, January 2013. 
- In 2015, the top percentile of wealth holders owned just over half of the world's wealth and the richest decile owned 87.7 percent. ${ }^{11}$ In 2014 , just 80 people controlled as much wealth as the bottom 50 percent of the world's population. ${ }^{12}$

- The highest income earners account for a very large and growing share (see Figure 1) of all personal income tax (PIT) revenues: the top one percent in the United Kingdom (UK) and US now account for around one-quarter and one-third respectively. ${ }^{13}$

From a taxation perspective, one significant feature of the HWI segment is that their income derives largely from capital, as distinct from earnings. Earned income is income from labor, such as wages, salaries, self-employment, professional fees, and pensions. Capital income is income derived from investments and property. As wealth increases, the percentage of total personal income derived from earned income sources drops significantly, with a corresponding increase in the percentage of total income from capital sources.

There are increased risks to tax revenues from capital income streams and tax administrations are often not well equipped to deal with these risks. Tax withholding and systems for the reporting of information on capital income streams are often not available, or are more subject to manipulation than earned income. As a result, tax administrations have to rely on self-reporting for many forms of capital income. Also, most tax administrations have tended to focus their compliance processes on earned income, operating income, business turnover, employment taxes, and self-employment and develop audit and other compliance programs to mitigate the risk of under-reporting. Two often-neglected areas of emphasis are: (1) income earned on capital and investment assets (both for individuals and legal entities); and (2) income from abroad.

HWIs (through their wealth managers) tend to invest their wealth wherever it is relatively secure and has reasonable rates of return, irrespective of international boundaries. They will generally have substantial investment portfolios located outside of the country in which they reside, so that income from abroad often makes up a significant portion of their income. As with domestic-source capital income, tax administrations often rely on self-reporting of foreign income, although exchange of information and cooperation between tax administrations is gradually being improved, as countries seek to tackle cross border tax evasion.

\footnotetext{
112015 Global Wealth Report, Credit Suisse.

12 Wealth: Having it all and wanting more, Oxfam Issue Briefing, January 2015.

${ }^{13}$ Current Challenges in Revenue Mobilization: Improving Tax Compliance, IMF, April 2015.
} 


\section{WHY DO LEADING TAX ADMINISTRATIONS GIVE SPECIAL ATTENTION TO THE HIGH-WEALTH INDIVIDUAL SECTOR?}

Tax administrations have limited resources to apply to the collection of taxes. They optimize collection by promoting voluntary compliance and by establishing programs to treat identified revenue risks and recover unreported or unpaid taxes, with appropriate penalties and interest. Revenue risk is the main determinant of how the limited resources are applied.

Although properly taxing the income generated by HWIs is administratively challenging, failure to do so can result in significant tax revenue loss. For this reason, many administrations have developed specialized programs to monitor their wealthiest individuals and encourage their tax compliance. Examples of the compliance initiatives developed by leading tax administrations are set out in Box 1 .

\section{Box 1. Examples of High-Wealth Individual Compliance Programs}

- A dedicated HWI unit - often within the large taxpayer office (LTO) - with highly skilled officers undertaking risk analysis, audit, and debt collection.

- Expanded information reporting covering entities and assets owned by HWIs, and mandatory disclosure of certain types of transactions.

- Measures encouraging voluntary compliance, such as pre-filing agreements, a rulings regime, and carefully designed voluntary disclosure schemes for past non-compliance.

- Comprehensive checks - risk reviews, audits, and prosecutions for the most egregious offenders-applied according to perceived risk level.

- Withholding taxes, those on rental payments having had some success in reaching HWls in India, for instance.

- Tightening laws, for example to prevent tax-free private use of assets held by companies, using companies and trusts to hold income at lower tax rates, and streaming income to "preferential" beneficiaries

Source: Current Challenges in Revenue Administration: Improving Tax Compliance, IMF, April 2015.

The need to focus on the HWI sector was addressed by the Organization for Economic Co-operation and Development (OECD) in a 2009 publication. ${ }^{14}$ The study points to four reasons for giving special attention to HWIs:

i. the complexity of their affairs;

ii. the amount of revenue at stake;

iii. their opportunity to undertake aggressive tax planning; and

iv. the need to preserve the integrity of the tax system by ensuring that the wealthy pay their fair share.

\footnotetext{
${ }^{14}$ Engaging with High Net Worth Individuals on Tax Compliance, OECD, 2009.
} 
The main recommendations of the publication (details at Appendix 1) included: gaining an understanding of aggressive tax planning; creating dedicated units to deal with HWIs; improving international cooperation; legislating to target aggressive tax planning; and exploring the concept of cooperative compliance. All of these measures have a place in a HWICP.

The challenges of ensuring tax compliance in the HWI sector are not exclusive to high income countries. Many low and lower middle income countries score highly for income inequality on the Gini coefficient ${ }^{15}$ and each country has its own share of the very wealthy. Of the 1,810 billionaires listed as by Forbes in 2016, some 30 percent are from the US and a further 14 percent from China, but there are 138 individuals (7.6 percent) listed, who are from low or lower middle income countries. Every tax administration must therefore face the challenge of ensuring compliance by the wealthiest individuals, so that the public can see that the administration is fair and evenhanded, and that no individual, no matter how wealthy or well-connected, is above the law.

The benefits from focusing on the HWI sector can be substantial. According to its annual report, the Australian Taxation Office's (ATO) HWI audit program yielded Australian Dollar (AUD) 680 million in liabilities and collected over AUD 440 million in cash from 800 compliance activities in 2014-15. ${ }^{16}$ In the United Kingdom (UK), the High-Net-Worth Unit of Her Majesty's Revenue and Customs (HMRC), which deals with taxpayers who have wealth of over Great Britain Pound (GBP) 20 million, brought in GBP 937 million in additional revenue between 2009, when it was set up and 2013-14. ${ }^{17}$ Indonesia reports assessments totaling Indonesian Rupiah (IDR) 107 billion arising from compliance actions by its High Wealth Unit in 2013.18

As information is exchanged revealing cross-border tax evasion, including evasion by HWIs, many countries have used voluntary disclosure schemes to deal with past noncompliance. As noted in Chapter II, much HWI wealth is held abroad, often in tax havens with strong secrecy laws. Various initiatives such as the European Union (EU) Savings Directive in 2003 and the US Foreign Account Tax Compliance Act (FATCA) in 2010 have brought much cross-border tax evasion to light. Often, not only has the foreign interest been untaxed, much of the funds invested represent undeclared income, and some may even be the proceeds of crime, or corruption. Tax administrations have to find ways to deal efficiently with the information received. Examples of successful voluntary disclosure schemes to deal with past non-compliance are in Box 2. From 2017, much more information will be exchanged under the automatic exchange of information (AEOI), and this will inevitably focus tax administrations' attention on HWIs.

\footnotetext{
${ }^{15}$ The Gini coefficient is a measure of the income distribution of a country's residents expressed as a percentage, where 0 percent represents perfect equality (i.e. each resident has the same level of income) and 100 percent represents perfect inequality.

${ }^{16}$ Commissioner of Taxation Annual Report 2014-15.

17 https://www.gov.uk/government/publications/issue-briefing-dealing-with-the-tax-affairs-of-wealthy-individuals/howwe-deal-with-wealthy-individuals.

18 Based on data issued by Indonesian Directorate General of Taxation.
} 


\section{Box 2. Examples of Voluntary Disclosure Initiatives}

Ireland. Using new access powers, the Irish revenue agency in 1999 obtained the names of bank account holders involved in a scheme to evade tax by disguising domestically held assets as foreign-owned. A limited-time offer was made to the perpetrators to come forward and pay all of the tax due plus penalty and interest (capped at 100 percent of the tax due) in return for immunity from prosecution and exemption from public disclosure. Around 3,700 voluntary disclosures were made, with payments of Euro (EUR) 227 million. Follow-up enforcement action against 8,500 taxpayers who did not come forward netted a further EUR 420 million in tax, penalties and interest. Subsequent special investigations in 2004 collected EUR 950 million from 15,000 individuals. Voluntary disclosure initiatives (VDIs) in 2005 (relating to untaxed funds in single premium insurance policies) and 2009 (undeclared tax liabilities associated with trusts and offshore structures) have continued to produce notable results. At end-2009, VDI and related initiatives have netted EUR 2.6 billion in delinquent taxes from 34,000 taxpayers.

United Kingdom. In 2007, breakthrough orders required five major banks to hand over information on 250,000 UK residents holding 400,000 offshore accounts. The revenue agency (HMRC) offered settlements on the basis that all back taxes be paid plus interest and penalty. Some 64,000 account holders accepted the offer and paid GBP 450 million. Around 10,000 of those who did not come forward were targeted for investigation. In 2009, HMRC secured further orders for the identities of offshore accounts and related activities from a further 325 banks. A VDI to allow these offshore account and asset holders to come forward on terms similar to the 2007 initiative was put in place.

United States. Based on information secured from major credit card companies, the internal revenue service (IRS) offered its first VDI in 2003 to taxpayers with unreported offshore income and bank accounts. About 1,300 taxpayers stepped forward and paid USD 75 million and, importantly, disclosed information of 400 promoters of offshore tax evasion schemes. In 2009, the IRS launched its second VDI on the back of promoter investigations and criminal prosecutions, and a successful court action against a Swiss bank (the bank, UBS, paid a fine of USD 780 million and disclosed names of US clients to settle the case). Over 14,000 taxpayers came forward, disclosing foreign accounts ranging from USD 10,000 to USD 100 million across several hundred banks in 70 countries.

\section{WHAT SHOULD A TAX ADMINISTRATION DO WHEN CONSIDERING SETTING UP A HIGH-WEALTH INDIVIDUAL COMPLIANCE PROGRAM?}

The first step towards implementing a HWICP is for a tax administration to make an assessment of its readiness to proceed and make any adjustments necessary to make the program feasible. An assessment of four principal areas is needed:

A. Alignment of a HWICP approach with the realities of the political environment

B. The extent to which fundamental legal authority and taxing rights are present.

C. The capacity of the administration to engage HWIs and their intermediaries.

D. The availability of necessary data and information. 
The purpose of the assessment is to identify any legal or procedural obstacles, which should be remedied as far as possible, before moving to the implementation of the program.

\section{A. Alignment of Compliance Goals with the Political and Economic Environment}

Alignment focuses mainly on whether a HWICP is consistent with the realities of the political and economic environment. Inconsistencies may exist between the objectives of the tax administration to maximize compliance and revenue from the HWI sector, and the political and economic implications of meeting those objectives. Account should also be taken of public and media perceptions of the need and fairness of a stronger compliance program for this sector. Any inconsistencies need to be resolved as far as possible. Box 3 discusses the alignment issue in more detail.

\section{Box 3. Alignment of a High-Wealth Individual Compliance Program with the Political, Economic, and Social Environment}

Political Environment: The direct support of the responsible Minister and his Cabinet colleagues is important, to address any tension between compliance goals and political reality. Briefings of key members of the legislature should take place and their support should be elicited. HWls often hold political posts or are Members of Parliament. They may be important backers of political groups and have access to high levels of government. It is vital to make clear the purpose and importance of a HWICP. Without broad and high-level political support, some HWICP tools may be unusable.

Economic Objectives: To attract wealth controlled by HWls, or to discourage their migration to other countries, governments may offer tax incentives in return for investment or economic activities. These can take many forms such as legislated tax exemptions and holidays, lower tax rates, delayed payment, etc. and are not always well costed or designed." Before initiating a HWICP, tax statutes should be reviewed to identify any areas where tax policies and incentives conflict with the objectives of a HWICP.

Public and Media Acceptance: The understanding and acceptance of a HWICP in the public mind is important. If the public perception is that those with the greatest wealth may be engaged in tax evasion or avoidance and not paying their full taxes, a HWICP will be welcomed. However, if the perception develops that the government is using the tax administration to pursue some HWls for political reasons, the integrity of the tax system and credibility of the tax administration risks being eroded-potentially resulting in increased noncompliance across the whole taxpayer base. When implementing a HWICP, it is essential to engender broad public recognition that the purpose is to ensure that the tax system is being fairly applied to all taxpayers, and that the HWICP program is part of a broad-based compliance strategy, designed to ensure that HWls are meeting their tax obligations.

Fairness: It is sometimes argued, incorrectly, that applying a special focus on compliance by one particular taxpayer segment violates the doctrine of equality before the law. This is a misuse or misunderstanding of the equality principle. Modern tax administration practice promotes fairness in society by applying limited resources to areas of greatest risk to the revenue base.

(continued on next page) 


\section{Box 3. Alignment of a High-Wealth Individual Compliance Program with the Political, Economic, and Social Environment (Continued)}

By tailoring service and enforcement programs to meet the needs and compliance risks of different taxpayer segments, the level of general compliance is increased and the most intensive treatment is reserved for those who pose the greatest risks, such as HWls. Nevertheless, a tax administration contemplating a HWICP may face this issue and will need to resolve the tension between the compliance goal and fairness objections through a strong communication program.

Judicial History: In some jurisdictions the courts may be a barrier to the implementation of a HWICP by, for example, not accepting direct or indirect proofs of income, not allowing access to some forms of financial records, issuing inconsistent decisions or taking too long to give decisions, or engaging in judicial actions that block timely compliance actions. This judicial landscape needs to be taken into account when considering a HWICP. It is likely that some, if not most, audit assessments will be appealed to the courts. HWls have the resources to access the best legal representation, and the additional tax at stake could make protracted litigation worthwhile.

*Good practices in the design and governance of such tax incentives is discussed in the IMF, OECD, World Bank and United Nations paper on Options for Low Income Countries' Effective and Efficient Use of Tax Incentives for Investment, at https://www.imf.org/external/np/g20/pdf/101515.pdf.

\section{B. Legal Authority to Support a HWICP}

The question of legal authority involves four issues: (i) whether the tax laws are extensive enough to tax the full scope of HWI income; (ii) whether the tax administration has authority to gather information and enforce the laws; (iii) whether there is specific anti-avoidance legislation; and (iv) whether privacy laws specify the protection and proper use of HWI data.

\section{Taxation Authority Over Income Streams}

A country's tax laws may not be fully developed for some income streams, such as income generated from equities, capital gains, and alternative investments. One report estimates that HWIs, on average, hold 57 percent of their wealth in equities, fixed income and alternative investments. ${ }^{19}$ Before initiating a HWICP, tax statutes should be reviewed to determine their impact on the various forms of earned and capital income anticipated within the HWI population and whether the tax laws give sufficient authority to tax all of those income streams. A framework is included at Appendix 2 that can be useful for this review. The review may show significant forms of personal income that are either exempted from tax by statute (in global tax systems), ${ }^{20}$ or omitted from taxation (direct source tax systems). ${ }^{21}$ This can be particularly the case for alternative investments, such as private investment

\footnotetext{
19 World Wealth Report 2015, Capgemini and Royal Bank of Canada Wealth Management.

${ }^{20}$ A global source income system begins with the tax code declaring all sources of income as taxable. The tax code then proceeds to exempt or differentiate certain forms of income as nontaxable and allows the taxpayer to deduct nontaxable income in computing taxable income.

${ }^{21}$ A direct source income system has no general income taxation clause; rather, it identifies particular income streams as taxable. If the tax code does not identify a source of income as taxable, then it usually is not. This approach can cause problems
} 
funds, private annuities, hedging transactions, commodity trading, financial derivatives, futures trading, currency trading, precious metals trading, oil and gas earnings, and collectibles investing. It is important to address such tax base issues as far as possible, prior to initiating a HWICP. HWIs are likely to arrange their affairs to take advantage of laws allowing the exemption or omission of certain forms of income.

\section{Authority to Gather Information and Enforce Laws}

Without a solid legal foundation to gather information and enforce compliance with general tax laws, a tax administration will not have the ability to run a HWICP. Six broad questions must be addressed:

- Does authority exist to gather, maintain, and analyze high wealth data? An issue may arise when tax procedure laws only allow data gathering when a formal audit, collection action, or investigation is authorized. Without a general authority to gather, maintain, and analyze data, the tax administration will not have the ability to perform the analyses required to determine tax contribution, compliance levels, tax gap, and risk analysis of HWIs. Some countries have enacted privacy statutes that prevent or restrict access to personal financial information of its residents: these hinder or limit the tax administration's analysis or review of HWI financial activity.

- Does authority exist to engage HWIs outside the standard audit structure? When a tax administration wishes to contact HWIs outside of the audit, tax collection, or investigative processes, it may find it does not have the authority to do so. For example, an advisory visit, or notices to remind HWIs of filing requirements, or to alert taxpayers to some omission are useful tactics to encourage voluntary compliance. A tax administration may be prohibited from such compliance-improving activities, and this would limit the tools available to a HWICP.

- Is the audit authority sufficient to audit HWIs and their personal financial information? Even in an audit context, because of the scale and complexity of their financial arrangements, a standard single year or multi-year comprehensive audit may not be the most appropriate tool to measure compliance of HWIs. Often a limited scope audit or other kind of enquiry may be the best approach, but it may need to be legislated for, if the law prescribes the scope of audit. Where legislation provides that audits must be completed within short timeframes, say 30 days, this may need amendment before a HWICP can be implemented. HWI audits are complex, especially when dealing with controlled companies and income from abroad, and can often span several months. Similarly, it is often advisable to audit HWIs in tandem with the companies they control. Again, the law should be reviewed to ensure that the tax administration has sufficient flexibility on audit scope to enable simultaneous audit and other types of intervention. Some jurisdictions prohibit access to personal financial records without a court order, or have other provisions making access to and audit of financial records difficult.

- Where does the burden rest to prove the source of funds for unexplained wealth? During an audit, it may become apparent that declared income and known sources of

for tax administrators when an income item cannot be attached to a direct source or comes from an unlegislated source.

Technical Notes and Manuals 17/07 | 2017 
funds are insufficient to finance the lifestyle and assets accumulated by the taxpayer. For example, an examination of known bank accounts may not reveal the source of funds for asset purchases. For HWIs, it may be particularly difficult to track the flows of funds for wealth accumulation and establish whether untaxed income was a source. Indirect methods are often used to determine taxable income where the source of funds for bank deposits or large asset purchases cannot be identified, but such methods cannot be used to establish a tax liability if the law places the burden of proof for an assessment on the tax administration. To support a HWICP, and audit generally where records are missing, the burden of proof should be on the taxpayer to substantiate the taxable or nontaxable source of funds for bank deposits and major asset acquisitions. Gaps in this area are an impediment to a HWICP.

- Does the authority exist for exchange of information with other jurisdictions? National borders do not confine the financial affairs of HWIs, as investments will be made and income received wherever the capital can generate the best return with relative security and a degree of privacy. Proper taxation of HWI income requires legislation and tax treaties that specifically permit the exchange of information with competent authorities in other jurisdictions. Recent developments and awareness of the scale of revenue loss from funds hidden across borders and in tax havens has improved the flow of information between taxation authorities. ${ }^{22}$

\section{General anti-avoidance provisions}

One of the characteristics of the HWI population is that they have the resources to obtain the most expensive financial and tax planning advice. This factor, coupled with a natural desire to reduce the scale of tax contribution, and keep wealth intact for successive generations, gives rise to a lively market in aggressive tax planning. With aggressive tax planning, the fine line may be crossed between the prudent arranging of financial affairs to minimize tax liabilities, and avoidance, which uses artificial transactions and instruments to minimize liabilities, in ways that the law did not intend. Tax laws in many countries include general anti-avoidance provisions to limit revenue losses through avoidance schemes. An IMF Tax Law Technical Note gives more information on this subject, including a sample General Anti-Avoidance Rule (GAAR). ${ }^{23}$

\section{Data security}

Data security is paramount for this sensitive population of taxpayers and it is important that the law provides for data protection. Where a tax administration has legal authority to gather information about wealthy individuals, including information from financial institutions, strong legal protections need to be in place to prevent taxpayer information loss, theft or misuse. As

\footnotetext{
22 See Appendix VIII Initiatives on International EOI at Current Challenges in Revenue Administration: Improving Tax Compliance, IMF, April 2015.

${ }^{23}$ Introducing a General Anti-Avoidance Rule: Ensuring That a GAAR Achieves Its Purpose, IMF Technical Note, January 2016.
} 
well as legal protection of data, procedures need to be in place to ensure that HWI information is only disclosed to staff members who have been approved and have a specific need for such access.

\section{Evaluation of the Capacity to Engage with HWIs and their Intermediaries}

Establishing readiness for a HWICP requires an evaluation of the existing capacity of the tax administration to undertake the program. The question of capacity involves three issues: (i) whether the audit function is sufficiently developed and has the right staff, skills and procedures to engage effectively with HWI sector; (ii) whether a range of other compliance tools are in place; and (iii) whether procedural and technical guidance is available.

\section{Audit Function}

Where a tax administration has had little past compliance focus on HWIs, compliance programs and audit skills focused on capital sources of income and capital accumulation may need to be developed. An assessment should be made of the institutional capacity in audit: a threshold level of functional competence must be established before embarking on a HWICP.

Audit Staff: Highly skilled and knowledgeable staff must be assigned to a HWICP. They must have extensive audit experience across PIT, corporate income tax (CIT), and capital taxes. They should have formal qualifications in accountancy, law or economics and have in-depth knowledge of the tax code, including provisions relating to capital taxes, complex business environment and the international environment. They must display maturity and impeccable integrity and be competent and confident enough to be on equal terms with the team of highly-paid tax professionals and lawyers representing the HWI.

Audit Techniques: These may need to be updated or developed where the PIT audit program has only focused on self-employed individuals. Auditing for personal income requires forensic auditing skills that differ from a typical audit, focused on accounting records and invoices. HWI audits focus on capital accumulation and missing income; this requires mastering audit techniques such as the direct proof of income method, or the indirect proof of income method. ${ }^{24}$ These techniques have to be developed in some countries.

Audit Procedures: Simultaneous auditing of HWIs and the legal entities they control is recommended, because their financial affairs are highly integrated and an examination of the transactions between the connected parties can identify potential for tax avoidance or evasion. Even where the law allows simultaneous audits, many tax jurisdictions separate their audit functions between legal entities and individuals and do not have a process for integrated audit. Issue-driven or limited scope auditing is a valuable technique for HWIs where financial activities

\footnotetext{
${ }^{24}$ Direct methods rely on verification of specific items of income against source documents. Indirect methods involve the determination of income through analysis of cash flow or capital reconciliations to identify income sources and extrapolate income figures.
} 
are extensive, and comprehensive audit is impractical and inefficient. Procedures and manuals may have to be modified to allow for the necessary flexibility in audit procedures.

\section{Compliance tools}

Audit is not the only tool needed to implement a HWICP: an analysis of all compliance tools is needed. ${ }^{25}$ An administration considering the introduction of a HWICP should examine the full range of tools available to support and enhance the compliance level of the HWI segment. Box 4 summarizes what a compliance toolbox might contain; each element should be examined to see whether the tools exist, and if so, whether they need to be further developed. An administration should also consider where the various compliance tools are located in the organizational structure, and what linkages need to be put in place to best support a HWICP.

\section{Box 4. Compliance Treatment Tool Box \\ - Legislation \\ - Technical procedures \\ - Tax guidance \\ - Taxpayer outreach \\ - IT applications \\ - Taxpayer service \\ - Instruction guides \\ - Website information \\ - Website applications \\ - Tax form changes \\ - External stakeholders \\ - Education \\ - Research and studies \\ - Media \\ - Information reporting \\ - Tax withholding \\ - Sanctions \\ - New data sources \\ - Notices and letters \\ - Organizational change \\ - Training \\ - Audit \\ - Compliance projects \\ - Collection \\ - Penalties and fines \\ - Criminal investigations}

\section{Technical guidance}

An analysis should be made of the current procedural and technical guidance available to deal with the HWI sector. Because of the complexity of their affairs, difficult issues will arise about tax treatment of certain transactions, and staff will need a resource for answering difficult technical questions as they arise. Technical guidance also includes publications, tax forms, notices, outreach, pamphlets, and guidance for specific issues, such as income from abroad, or anti-avoidance provisions. ${ }^{26}$

\footnotetext{
${ }^{25}$ A full table of compliance tools and a supporting check sheet are included at Appendix 3.

${ }^{26}$ An example of how technical advice is made available to HWIs can be found on the ATO website: https://www.ato. gov.au/Business/Privately-owned-and-wealthy-groups/.
} 


\section{Data and Information}

The final factor in determining readiness is adequacy of data and information. Data issues fall into three categories: (i) the extent of information available to identify the highwealth population; (ii) the degree to which the information allows analysis of tax contribution, compliance levels, tax gap, and compliance risks; and (iii) the availability of data exchange and international cooperation under tax treaties. Access to and adequacy of data available to an administration should be reviewed and any gaps identified when assessing readiness for a HWICP.

\section{HOW SHOULD A HIGH-WEALTH INDIVIDUAL COMPLIANCE PROGRAM BE STARTED, COMMUNICATED, AND STAFFED?}

\section{Establishing a Development Team}

A small development team is needed for the completion of the initial stages of program research, development, and coordination. When a decision has been made to proceed with a HWICP, the next step is to establish a small development team, charged with compiling a report summarizing the strengths and weaknesses in the current system, and making recommendations for changes needed to remedy shortfalls identified in the readiness assessment described in Chapter IV. This is a temporary activity, lasting six to twelve months. The team needs to have a strong mandate and clear terms of reference. It should report frequently to the head of the tax administration or a deputy head responsible for operations.

\section{Defining the HWI Population}

An administration should start with a small number of HWIs. When addressing tax compliance by HWIs is a new endeavor for a tax administration, it is best to limit the initial population of HWIs included in a compliance program to a small number, so that experience can be developed. Starting with a large population of HWIs using a lower wealth cut-off can overwhelm an administration and may thus be ineffective and even counterproductive.

A good group with which to start are the UHWIs (those controlling wealth of USD 30 million or more, see Chapter II). It is estimated that the top one percent of HWIs account for 35 percent of all HWI wealth, ${ }^{27}$ so ensuring high compliance from this group could lead to significantly higher tax receipts; conversely, there is potential for significant revenue leakage when compliance is low. These very wealthy individuals usually comprise a small population in moderate sized economies. Smaller economies may use a lower cut-off for a HWICP, if the UHWI population is very small, but whatever the cut-off, it makes sense to narrow the focus to the very wealthiest. Focusing on the very wealthiest meets the criterion of using limited tax

27 2015World Wealth Report, Capgemini \& Royal Bank of Canada Wealth Management. 
administration resources to deal with a manageable tax population that can have a significant tax impact. That is not to say that HWIs with wealth below the cut-off should be ignored, just that it is better initially to select a manageable group to build up experience and expertise.

\section{Publishing the Strategy}

When a tax administration has made a thorough assessment of its readiness to implement a HWICP, remedied obstacles as far as possible, and decided to proceed, it needs to devise and document its HWI Compliance Strategy (HWICS). The strategy may start out as a component of its overall strategy to improve compliance.

A HWI Compliance Strategy document will answer such questions as:

- Why is there need for a HWICP?

- What is the intent of the HWICP?

- What benefits are expected? When are these expected?

- Which taxpayers will be included in the program?

- What authority exists for such a program?

- What type of methodology or model will be used to administer the program?

- How will the HWICP be staffed and managed?

- Who has approved the HWICP?

It is suggested that the HWICS be agreed with the Minister of Finance, or other Minister to whom the tax administration reports, and have broad political support as outlined in Chapter IV. The purpose and objectives of the HWICS should be actively communicated internally and externally, and be reflected in published documentation of the tax administration's annual work plans.

\section{Implementation Phase}

The implementation phase of the HWICP requires a program management office with a permanent staff that has the appropriate skills and knowledge. The head of the program and the staff are responsible for risk mapping, articulation of risk, determination of desired outcomes, development of compliance treatments, managing delivery of treatments, monitoring, measurement, and qualitative evaluation of results. These tasks are explored in more detail in Chapter VI.

\section{Staffing the Operational Unit}

In the physical setting up of the HWICP, to ensure effective management and support, it is recommended that the HWICP be centralized within its own operational unit, which reports to a level of Deputy Director General, or higher. Staffing numbers will depend on the size and complexity 
of the case base. ${ }^{28}$ The two areas that usually require fulltime staff within the operational unit are audit and taxpayer services. HWI audits require highly specialized skills and training (see Chapter IV). It is recommended that HWI audit activities be segmented into permanent specialized audit groups, in much the same way that large taxpayer auditors are generally organized in most tax administrations; the same applies to taxpayer service specialists, who need to be experienced, capable and knowledgeable.

\section{CAN THE COMPLIANCE RISK MANAGEMENT MODEL BE USED AS A BASIS FOR A HIGH-WEALTH INDIVIDUAL COMPLIANCE PROGRAM?}

A useful way to approach the development task is to use a standard framework for resource allocation based on risk, such as the CRM model, described in Figure 2.

Figure 2. The Compliance Risk Management Process

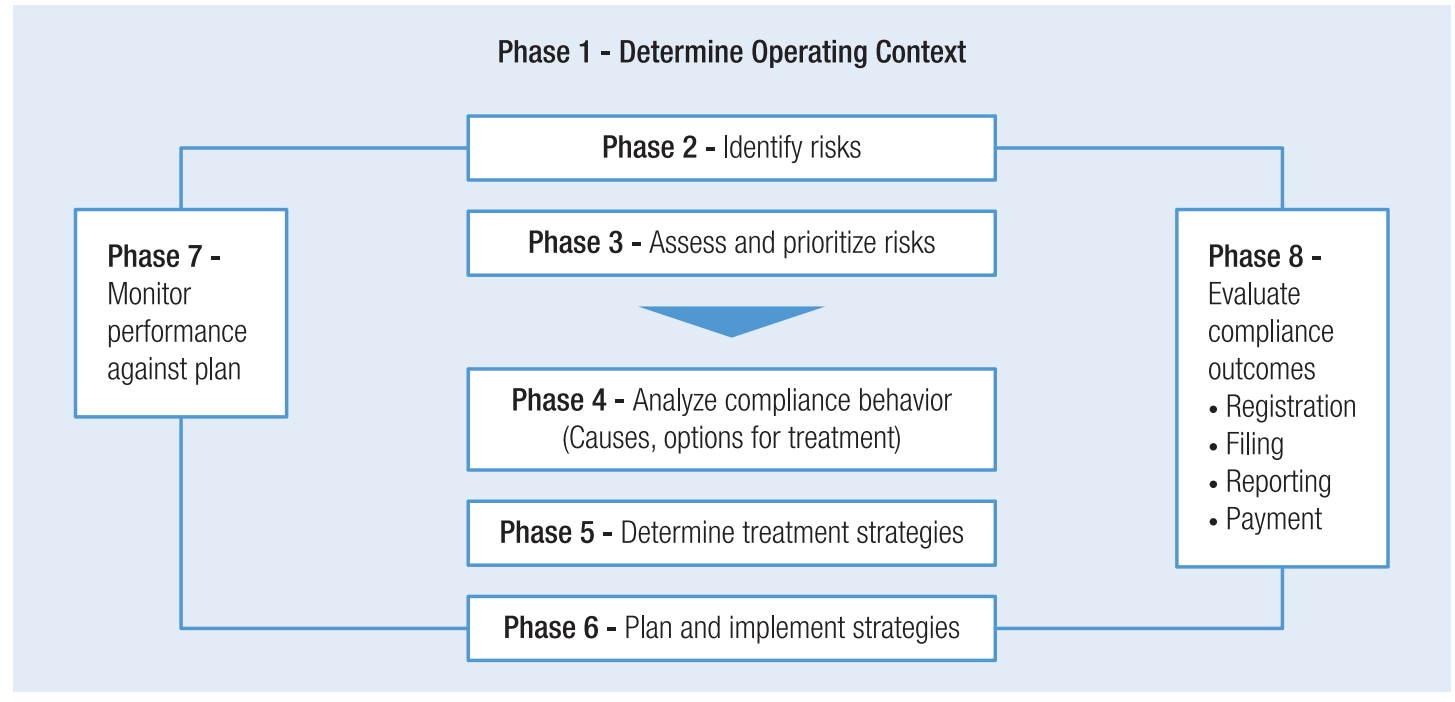

Source: Organization for Economic Cooperation and Development (adapted).

A strong audit capability is an important aspect of a HWICP, as discussed in Chapter IV, but other treatments are needed too. Tax administrations have in the past relied on audit as the main recourse for addressing noncompliance. While audit can be an effective tool for recovering underreported tax, interest and penalties in a given case, and to some extent in encouraging compliance in others, it has limited success in changing compliance behavior and enhancing voluntary compliance. Furthermore, it is an expensive tool for treating non-compliance and because resources are limited, it will never recover more than a small percentage of the tax gap. Modern tax administrations now regard increasing voluntary compliance as the primary objective, and tax recovery as the secondary objective; a HWICP based on the CRM model follows the same logic.

\footnotetext{
${ }^{28}$ The OECD study Tax Administration 2015: Comparative Information on OECD and Other Advanced and Emerging Economies shows a variety of HWI to staff ratios, with Canada and Ireland showing a ratio of about 25:1.
} 
The CRM model is a process designed to promote compliance by identifying risks in taxpayer segments and applying the simplest and most cost-effective treatments to mitigate the risks and raise compliance levels. The stages of the process need to be documented and the process is cyclical, as described in the following paragraphs, which show how the CRM model can be adapted to provide a basis for a HWICP.

\section{Phase 1: Define-Identify the Population}

Existing tax administration data is an obvious place to start with identifying the HWI population. Commercial media and the internet are also useful sources of background information. A number of research firms, who follow the investment and wealth activities of UHWIs, sell this information to commercial and government customers. With an adequate budget for the HWICP, these data can be purchased for use in the task of identifying and building profiles of the target population.

Once the population has been identified, the tax administration should build a profile of each HWI. The profile should identify and link the connected parties and controlled entities. It should also review the compliance history for each identified HWI for the last three years, to understand their compliance behavior and their contribution to PIT revenues. The review should focus on the four fundamental tax obligations: registration, declaration, accuracy, and payment. It should identify total tax payments by tax type, and should include audit history, as well as unpaid tax debts. This compliance history provides the basic information about the HWI population. The more complete this process is, the better the initial understanding of the HWI population will be.

\section{Phase 2: Identify HWI Compliance Risks (Risk Mapping)}

The goal of risk mapping is to identify compliance risks based on manageable issues organized by tax type, income stream, tax potential, and compliance level. This process is applied to the HWI population as a whole, and is described in more detail in Box 5.

\section{Phase 3: Assess and Prioritize Compliance Risks}

The task here is to assess the significance of the risks identified and prioritize them on the basis of compliance outcome and available resources. Outcomes (which should be quantifiable and achievable) are not limited to enforcement results—they include such measures as change in voluntary compliance, change in total tax reported, change in total tax collected, impact on tax gap, tax recovery, etc., in determining effectiveness. Outcomes align with the compliance risk, so they can be focused on a specific tax form, or an income stream (for example, sale of stocks and shares). Clarity about the desired outcome can assist in designing an appropriate treatment for the compliance risk targeted. 


\section{Box 5. Elements of the Risk Mapping Process}

Baselines: A baseline represents the starting point for measuring the impact of the HWICS. The baselines already set at Phase 1 measure many facets of the HWI compliance history, such as tax paid, returns filed, returns timely filed, collection history, and audit history. It is advisable that a baseline be set for each income stream reportable.

Trend Analysis: Trend analysis is the practice of attempting to identify a pattern or trend in data. It uses the baseline information as its starting point and adds each tax period filing, payment, income stream level, etc. to determine the compliance trend direction, or impact of treatments.

Voluntary Compliance Level (VCL): Most tax systems rely to some extent on selfassessment and promote voluntary compliance by encouraging and assisting taxpayers with registering, filing, reporting, and paying self-reported taxes correctly. To determine success, tax administrations strive to compute the VCL for each type of tax return required. Each of the four fundamental requirements of registering, timely filing, correct reporting, and timely payment of taxes has a separate VCL. VCL computations are suggested for each type of income stream reportable by HWls.

Tax Gap: Simply put, the tax gap represents the percentage difference between the tax which ought to be paid (tax potential) and the tax actually paid, usually computed over a 12-month period. It is difficult to compute the HWI tax gap with any degree of accuracy, but every effort should be made to compute components of it, or to estimate it. Advice on computing a tax gap is beyond the scope of this technical note--administrations seek expert guidance on this subject.

Information: Information from third party returns, or from other tax jurisdictions under AOEl, or from media reports (about for example mergers and acquisitions, or purchase of collectibles, or trophy homes) needs to be added to the risk map. While these information sources may point to individual risks, rather which risks for the segment, they may also identify significant risks that need treatment, and present opportunities for well managed voluntary disclosure schemes, or invitations to self-review.

\section{Phase 4: Analyze Compliance Behavior}

The CRM approach to HWI compliance seeks to learn the causes of noncompliance and to take a cross-departmental approach to addressing these causes. This process works best when a cross-section of internal stakeholders (such as audit, collection, information technology, taxpayer service, etc.) reviews the identified risks from diverse perspectives to determine causes. The establishment of a Compliance Council, at which each tax administration function has a representative, helps to foster this broadened approach, and can prove very useful for a HWICP in promoting voluntary compliance.

Establishing a system of meeting and exchanging ideas with external stakeholders can provide additional insights into factors driving compliance or creating noncompliance. 
Some examples of external stakeholders, who play a role in directly or indirectly supporting or governing HWIs in their financial affairs, are listed in Box 6. It may be difficult to open lines of communication initially with these stakeholders, but they can provide important insights on what is needed to enhance compliance. Meeting with these stakeholders on a periodic basis to discuss developments and compliance concerns can facilitate the design of the treatment strategy.

\section{Box 6. Sample External Stakeholders}

\begin{tabular}{ccc} 
Non-government & Government \\
${$\cline { 1 - 1 }$} }$ & Ministry of Finance \\
Legal profession & Securities commission \\
Banking & Banking regulators \\
Investment industry & Anti-money laundering agency \\
Civil society organizations & Fraud investigation units \\
Real estate industry & Local government
\end{tabular}

\section{Phase 5: Determine Treatment Strategies}

Having identified the risks, the desired outcomes and the causes of poor compliance behavior, the tax administration must decide which tools in the compliance toolkit provide the most appropriate and cost-effective treatment, designed to deliver the desired outcome. The exclusive use of audit staff for this purpose tends to end with a predictable conclusion that these taxpayers need to be audited. While audit provides an experienced voice in identifying causes of noncompliance, it may not always be quick to identify non-audit treatments or preventative measures. Audit, collection, and taxpayer service provide the basic tools for treating noncompliance, but if the goal is to change compliance behavior, other tools (for example legislative amendments, changes to form design, or media campaigns) need to be considered. Box 1 gives further examples of treatments that have been successfully applied to HWIs. A compliance treatment tools check sheet is included at Appendix 3; it may be useful in considering the range of treatments available.

Tax administrations that have gained experience in dealing with the HWI sector, and have developed strong audit capacity and other treatment strategies, may want to consider a cooperative compliance ${ }^{29}$ approach. This approach essentially provides for an agreement between the HWI and the administration that the administration will provide enhanced service, clarity of interpretation and advance rulings while the HWI in turn commits to absolute transparency and full disclosure.

${ }^{29}$ Co-Operative Compliance: A Framework, OECD, 2013. 


\section{Phase 6: Implement Action Plans}

An action plan is needed to ensure that the prioritized treatments are applied. This should specify what is to be done, when, how, and by whom. The action plan must be flexible enough to be adjusted as new information becomes available, or if it becomes apparent that the results are poor, or unintended negative consequences are occurring.

\section{Phase 7: Establish Monitoring and Reporting Mechanisms and Performance Targets}

Effective monitoring requires compliance strategies with clearly defined and measurable objectives. The HWICP needs a quantitative and time-defined measurement system to determine whether results match the desired outcomes and whether the program is delivering on the strategy.

\section{Phase 8: Qualitative Analysis of Outcomes}

Qualitative evaluation adds meaning and understanding to the results determined in the quantitative measurements. To justify the resources devoted to the HWICP and demonstrate its effectiveness, tax administrations need to be able to show the compliance benefits being achieved, as well as determine whether predicted outcomes are being realized. This analysis feeds into the risk mapping process, and so the cycle continues. 


\section{SUMMARY OF KEY POINTS}

- HWIs comprise a significant economic sector for tax administrations.

- HWI tax contributions account for a large and growing component of overall PIT due.

- The nature of HWI financial affairs creates substantial tax complexity for both HWIs and the tax administration to address.

- Income generated by HWI financial activities usually takes the form of capital income and often requires self-reporting.

- Several tax administrations initiate programs to improve compliance and/or recover undeclared tax from the HWI sector.

- Tax administrations need to define and identify the HWI population.

- Tax administrations are encouraged to prepare for a HWICP by first reviewing whether key factors necessary for success are in place:

- Will the HWICP conflict with other government policies?

- Are there adequate legal, tax, and administrative authorities for such a program?

- Does the tax administration have the capacity to engage HWIs?

- Does the tax administration have access to sufficient data to identify and analyze the HWI population?

- A formal readiness assessment will identify deficiencies and facilitate the initiation of changes necessary for implementation of a HWICP.

- A HWI Compliance Strategy should be developed to improve voluntary compliance and tax revenues from HWIs.

- A HWI Compliance Strategy requires a formal commitment from tax administrations and broad and high-level political support.

- A fully staffed HWI Compliance Program is necessary for most tax administrations to engage the high-wealth sector.

- Because of the complexity and revenue potential of this sector, staff in a dedicated HWI unit needs to have specialized skills, knowledge, and experience.

- It is recommended that the CRM model be used as the process for designing and carrying out the HWICS.

- This model focuses on identifying major risks and causes, and developing treatments to incrementally reduce the tax gap for the sector through improved voluntary compliance and enhanced recovery.

- The model focuses on outcomes and needs measurement and monitoring systems that provide quantitative and qualitative feedback.

- The model is cyclical, using results and new information to update its risk mapping, causes of risks, and treatment actions annually.

- A wide assortment of tools and treatments is available, many of which have been underused or are underdeveloped. 


\section{APPENDIX 1. KEY RECOMMENDATIONS OF THE ORGANIZATION FOR ECONOMIC COOPERATION AND DEVELOPMENT}

Experience suggests that firm action when combined with good compliance activity and good service can significantly improve compliance by HNWIs:

- Gaining a greater understanding of the risks posed by the HNWI segment by:

- looking at the types of aggressive tax planning (ATP) schemes in the marketplace, the suppliers of ATP, and the HNWI's motivation; and

- developing a strong commercial awareness of the broader concerns of HNWIs, including privacy, wealth preservation, and their ability to pass on wealth to future generations.

- Building an effective capability to manage tax risk by establishing an appropriate structure in tax administrations to deal with HNWIs and focusing resources by:

- creating dedicated units which are adequately staffed by experienced officials;

- establishing a framework for dialogue between senior revenue officials, HNWIs and their advisers; and

- balancing compliance activities with taxpayer service functions.

- Improve international co-operation at both a strategic and an operational level, including the use of regular meetings between heads of HNWI units and other specialists within tax administrations.

- Creating an appropriate legislative framework targeted at specific aggressive tax planning risks by taking a holistic approach to focus our strategies.

- Explore how the concept of co-operative compliance could be applied to the HNWI segment, by (where appropriate):

- considering the use of dedicated contact points;

- developing a pre-filing program or advance ruling program;

- involving the advisers of HNWIs in the development of legislation that specifically affects their clients;

- emphasizing the need for transparency and disclosure that goes beyond what is statutorily required; and

- providing clarity on key issues of concern to taxpayers wishing to make a full disclosure regarding past non-compliance

Source: A summary from Engaging with High-Net Worth Individuals on Tax Compliance, OECD, 2009.

Technical Notes and Manuals 17/07 | 2017

CInternational Monetary Fund. Not for Redistribution 


\section{APPENDIX 2. QUESTIONS REGARDING THE TAXATION OF PERSONAL INCOME}

\begin{tabular}{|c|c|c|c|}
\hline INCOME TYPE & TAXABLE (YES OR NO) & APPLICABLE TAX RATE & COMMENTS \\
\hline \multicolumn{4}{|l|}{ EARNED INCOME } \\
\hline \multicolumn{4}{|l|}{ Wages and salaries } \\
\hline \multicolumn{4}{|l|}{ Self-employment income } \\
\hline \multicolumn{4}{|l|}{ Professional and service fees } \\
\hline \multicolumn{4}{|l|}{ Farming income } \\
\hline \multicolumn{4}{|l|}{ Pension income } \\
\hline \multicolumn{4}{|l|}{ Royalty income } \\
\hline \multicolumn{4}{|l|}{ Gambling income } \\
\hline \multicolumn{4}{|l|}{ CAPITAL INCOME } \\
\hline \multicolumn{4}{|l|}{ Interest income } \\
\hline \multicolumn{4}{|l|}{ Dividend income } \\
\hline \multicolumn{4}{|l|}{ Rental income } \\
\hline \multicolumn{4}{|l|}{ Brokerage account income } \\
\hline \multicolumn{4}{|l|}{ Sale of publicly traded (open) stocks \& equities } \\
\hline \multicolumn{4}{|l|}{ Sale of close company stock } \\
\hline \multicolumn{4}{|l|}{ Sale of immovable property } \\
\hline \multicolumn{4}{|l|}{ Sale of movable property } \\
\hline \multicolumn{4}{|l|}{ PASS-THROUGH INCOME } \\
\hline \multicolumn{4}{|l|}{ Partnerships } \\
\hline \multicolumn{4}{|l|}{ Trusts } \\
\hline \multicolumn{4}{|c|}{ CORPORATE PAYMENTS FROM CONTROLLED COMPANIES ${ }^{30}$} \\
\hline \multicolumn{4}{|l|}{ Distributions of cash } \\
\hline \multicolumn{4}{|l|}{ Distributions of property } \\
\hline \multicolumn{4}{|l|}{ Loans to shareholders } \\
\hline \multicolumn{4}{|l|}{ Payment of personal shareholder expenses } \\
\hline \multicolumn{4}{|l|}{ Use of corporate property by shareholders } \\
\hline \multicolumn{4}{|c|}{ ALTERNATIVE INVESTMENTS ${ }^{31}$ (ADDITIONAL CAPITAL INCOME SOURCES) } \\
\hline \multicolumn{4}{|l|}{ Private equity funds } \\
\hline Private annuities & & & \\
\hline Hedging transactions & & & \\
\hline Commodity trading & & & \\
\hline Financial derivatives & & & \\
\hline Futures trading & & & \\
\hline Currency trading & & & \\
\hline Precious metals trading & & & \\
\hline Oil and gas royalty payments & & & \\
\hline Collectibles trading & & & \\
\hline
\end{tabular}

\footnotetext{
${ }^{30}$ The definition of a controlled company varies by tax jurisdiction. Generally, for high wealth purposes, a person who owns 50 percent of the voting stock of a company has established enough control to be able to influence or direct company payments. Likewise, if a person is an officer or director of the company, that person may be able to control payments from the company.

${ }^{31}$ An alternative investment is an investment in asset classes other than stocks, bonds, and cash.
} 


\section{APPENDIX 3. COMPLIANCE TREATMENT TOOLS CHECK SHEET}

A Customer/Client Knowledge: This grouping of tools includes data gathering, data analysis, and input from stakeholders to acquire knowledge regarding compliance risks and the drivers of those risks.

A1 Tax administration input and data

The tax administration collects and stores substantial amounts of HWI data collected from tax return filings, enforcement actions, and other sources. The tax administration has experience working with taxpayers and the companies they control. These data and experience are starting points for understanding HWI behavior.

A2 Taxpayer input Input from this sector often relies on outreach activities, seminars, surveys, and audit activities.

A3 Stakeholder input Input from external stakeholder groups provides a rich source of information regarding factors driving compliance or creating noncompliance.

A4 Taxpayer outreach

Scheduled outreach and educational seminars directed at HWls can be used to gather information and seminars on causes of noncompliance and opportunities to address these causes.

A5 Data collection and data mining

The collection of data beyond the information normally maintained by the tax administration from local government sources, other government agencies, and nongovernment sources.

A6 Information technology (IT) Often IT serves as the reservoir of all data collected by the tax administration. Understanding the potential of these data and creating systems to retrieve and analyze them can be beneficial in understanding taxpayer behavior, as well as identifying causes and effects for this behavior.

A7 Research and studies The completion of either internal or external studies on specific HWI issues or income streams is helpful in understanding taxpayer behavior.

B Compliance Services: This grouping of tools surrounds tax administration efforts to communicate correct tax registration, tax filing, and correct reporting of personal income tax information to taxpayers.

B1 Taxpayer service This refers to designated officers who assist HWls with questions on tax filing obligations, tax return preparation, application of tax law, accounts management, and general questions.

B2 Technical guidance

This refers to guidance provided and often published by tax administrations on specific tax topics or issues to assist taxpayers with complex areas of tax law.

B3 Call centers

Call centers can be used to assist HWIs with and may provide account management support. They can also be used to proactively contact HWls regarding upcoming filing obligations and non-filed returns.

B4 Publications This is a published form of taxpayer service where tax administrations provide guidance on filing and pamphlets obligations, return preparation, application of the law, and general questions.

B5 Website information

This is an electronic service where tax administrations provide guidance on tax filing obligations, printable forms, return preparation, application of the law, and general questions.

B6 Website applications

Website applications can provide useful tools to expedite and enhance compliance through applications that support proper registrations, filing, reporting, and payment of personal income tax obligations. Electronic filing, electronic payment, and electronic taxpayer service are some processes that may lend themselves to electronic applications.

\section{CInternational Monetary Fund. Not for Redistribution}




\section{APPENDIX 3. COMPLIANCE TREATMENT TOOLS CHECK SHEET (CONTINUED)}

B7 Accounts management

How a tax administration manages HWI tax accounts can play a part in HWI compliance. The electronic or paper processes in place dictate specific actions and determine the usefulness of the data for compliance purposes. The timeliness and accuracy of account management data is a vital element in the compliance process. The accessibility of this information may make a difference in voluntary compliance.

B8 Notices and letters

Notices and letters provide a written form by which the tax administration provides reminders, requests for information, or guidance on filing obligations, forms due, return preparation, application of the law, and general questions.

C Procedural Change: This grouping of tools looks at the laws, procedures, processes, and systems in place and their roles in supporting voluntary compliance or creating noncompliance.

C1 Legislative change

Recommendations for legislative change can be a powerful tool for compliance when the legislative framework is negatively impacting on compliance or is not robust enough to support compliance. There may be a need to provide a legislative framework for updated or new tax administration authorities.

C2 Tax procedures Tax procedure change is a useful tool for compliance when the current procedures are negatively impacting on, or not properly supporting compliance. Looking internally at the procedures in place often spots unintended roadblocks.

C3 Tax forms and instructions

The clarity and usefulness of tax forms and the supporting instructions plays a major role in supporting compliance. Forms that are incomplete, vague, or overly complicated lead to noncompliance. The same applies to instructions for using forms.

C4 Returns and payment processing

This refers to the systems for managing tax returns, forms, payments, and other correspondence. Evaluating how effectively these systems operate and their impact on compliance provides another useful tool.

C5 Information reporting

Information reporting by employers, financial institutions, companies, and other vendors is a powerful tool for enhancing compliance. Seeking opportunities to increase sources of information reporting (including from other tax administrations) for HWls, where appropriate and reasonable, can have a positive impact on voluntary compliance and enhance recovery opportunities.

C6 Tax withholding

Tax withholding by employers, financial institutions, companies, and others is another powerful tool for maximizing compliance. Seeking opportunities to increase withholding on income streams received by HWls, where appropriate and reasonable, has a positive impact.

D Enforcement: These tools provide incentives to register, file, and pay correctly and in a timely manner, as well as tools to recover or collect unpaid taxes.

D1 Collection This refers to the system to pursue assessed but unpaid taxes that have accumulated.

D2 Penalties and fines This refers to legislated penalties and fines assessed for late filing, late payment, inaccurate reporting, failure to maintain records, and other noncompliant behavior.

D3 Sanctions

This refers to penalties or other means of discipline used to provide incentives for compliance with rules and regulations.

\section{CInternational Monetary Fund. Not for Redistribution}




\section{APPENDIX 3. COMPLIANCE TREATMENT TOOLS CHECK SHEET (CONTINUED)}

\begin{tabular}{|l|l|l|}
\hline \multicolumn{1}{|c|}{ TOOL } & \multicolumn{1}{c}{ DESCRIPTION } \\
\hline D4 & Investigation & This refers to criminal investigation and criminal prosecution for intentional noncompliance with tax laws. \\
\hline E & Audit: Audit is an enforcement tool but is separately stated because it is the prime compliance tool used by many tax administrations.
\end{tabular}

E1 Document matching This refers to the process of matching tax documents received against the self-reported information. For HWls, the matching program concentrates on income documents from companies, financial institutions, and other payers to the information reported on returns. Many tax agencies refer to this process as a control when reviewing a tax return based on a mismatch of income information received and that reported by the taxpayer.

E2 Automated audit This uses computers to match information reports on income received to income reported. If program a mismatch is identified, the tax administration issues a computer-generated notice to inform the taxpayer that unreported income has been detected. The notice provides the corrected tax, penalties, and interest due. The notice requests payment or that the taxpayer provides evidence that refutes the conclusion that tax is due.

E3 Auditing for income

A PIT audit concentrates on identifying a HWI's personal income and determining taxability of that income. The tax administration determines if reportable tax income has been accurately reported and taxed. Direct and indirect audit proofs are the two primary audit methods applied.

E4 Taxation of unexplained capital

The indirect audit proof may identify receipts, deposits, payments, and purchases where a source of funds for these items remains unidentified. Taxing of unidentified funds as income can be a valuable compliance tool.

E5 Simultaneous audit

Simultaneous audit of HWls and the legal entities they control is recommended when engaging HWIs. There is a high correlation of transactions between HWls and the companies they use to manage their financial affairs. Without a process that allows the audit of the HWI and selected controlled companies, the audit picture will be incomplete and allow the HWI to manipulate the tax system and may lead to tax avoidance or unchecked evasion.

E6 Limited scope audit

Limited scope refers to the concept of selecting and auditing only key issues during an audit. In many jurisdictions, all items must be reviewed during an audit. The limited scope concept is a valuable technique when engaging HWls. Their financial activities are often extensive, so a total audit is impractical.

E7 Audit cycle

Audit cycle is the length of time legally available to complete an audit. These cycles vary from country to country, with cycles noted of three months, six months, one year, and up to three years in some countries. It is recommended that an extended audit cycle be allowed for HWl's to give sufficient time to complete a quality audit.

F Income from abroad: IFA taxation is a very difficult area of tax law to enforce. The following list of initiatives provides considerable guidance on tools and treatments for improving compliance in this area.

F1 Global Forum on Transparency

The Global Forum was restructured in September 2009 in response to the G20 call to strengthen implementation of these standards. The Global Forum has 124 members on equal footing and is the premier international body for ensuring the implementation of the internationally agreed standards of transparency and exchange of information in the tax area. Through an in-depth peer review process, the restructured Global Forum monitors its members to ensure that they have fully implemented the agreed standard of transparency and exchange of information. It works to establish a level playing field, even among countries that have not joined the Global Forum. 


\section{APPENDIX 3. COMPLIANCE TREATMENT TOOLS CHECK SHEET (CONTINUED)}

\begin{tabular}{|l|l|l|}
\hline \multicolumn{1}{|c|}{ TOOL } & \multicolumn{1}{c|}{ DESCRIPTION } \\
\hline F2 & Exchange of information & $\begin{array}{l}\text { This refers to the exchange of non-resident financial account information with the tax authorities in } \\
\text { the account holder's country of residence. }\end{array}$ \\
\hline F3 & $\begin{array}{l}\text { Foreign Account Tax } \\
\text { Compliance Act (FACTA) }\end{array}$ & $\begin{array}{l}\text { FATCA focuses on reporting financial accounts held by institutions offshore on behalf of US } \\
\text { taxpayers. The objective of FATCA is the reporting of foreign-held assets, with withholding as } \\
\text { the cost of not reporting. }\end{array}$ \\
\hline F4 & $\begin{array}{l}\text { OECD/G-20 Base } \\
\text { Erosion and Profit } \\
\text { Shifting (BEPS) Project }\end{array}$ & $\begin{array}{l}\text { The BEPS action plan provides steps to counter planning strategies used by taxpayers } \\
\text { who misuse tax rules to artificially shift income to jurisdictions with low or no income } \\
\text { tax requirements. }\end{array}$ \\
\hline
\end{tabular}


International Monetary Fund

Fiscal Affairs Department

700 19th Street NW

Washington, DC 20431

USA

Tel: 1-202-623-8554

Fax: 1-202-623-6073
ISBN: 978-1475592948

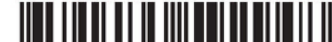

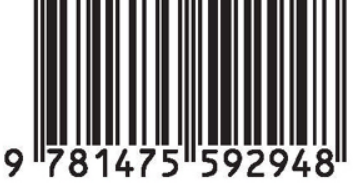

